\title{
市販粒状落花生及びナッツ製品のアフラトキシン污染調査 のための小規模サンプリング計画についで*1
}

(昭和 58 年 3 月 4 日受理)

$\begin{array}{ll}\text { 山本勝彦*2 } & \text { 坪内春 }{ }^{* 2} \\ \text { 久田和 } *^{* 2} & \text { 坂 部美 雄 }{ }^{* 2}\end{array}$

\section{A Plan for Small-Scale Sampling of Retailed Grainy Peanut and Nut Products for Surveying Aflatoxin Contamination}

(Studies on Mycotoxins in Foods. V)

\author{
Katsuhiko Yamamoto, Haruo Tsubouchi, Kazuo Hisada \\ and Yoshio SAKABE
}

(Nagoya City Health Research Institute; 1-11, Hagiyama-cho, Mizuho-ku, Nagoya, Japan)

\begin{abstract}
A plan for sampling of retailed grainy peanut and nut products was designed on the basis of the law of binomial distribution to search for lots with aflatoxin (AF) contamination of $0.1 \%$ or more in kernel number and to estimate the proportion of contaminated kernels.

In this plan a grainy sample $(500-1000 \mathrm{~g})$ was divided into several subsamples of equal weight $(100-200 \mathrm{~g})$ followed by comminution and re-mixture of comminuted subsamples, and $\mathrm{AF}$ analyses were performed on the mixed subsamples to estimate the contamination level of the original sample and on each subsample to obtain the proportion of contami. nated kernels.

In a 1981-1982 survey of 144 market samples collected in the Nagoya district, 2 lots of peanut samples were AF positive with $A F B_{1}$ contamination levels of 40.0 and $418 \mathrm{ppb}$; the proportions of contaminated kernels were 0.17 and $0.60 \%$, respectively.
\end{abstract}

(Received March 4, 1983)

Key words: アフラトキシン污染調査 survey of aflatoxin contamination; 小規模サンプリング small scale sampling; 二項分布 binomial distribution; 落花生 peanut; ナッツ nut

\section{1. 緒 言}

昭和 46 年 3 月, 厚生省環食第 128 号の通達により, 落 花生及びその製品のアフラトキシン（以下 AF と略す） $\mathrm{B}_{1}$ の試験法が都道府県市の検査機関等に示され ${ }^{1)}$, その 後, 昭和 56 年 9 月環食第 204 号の通達により, ピスタチ オナッツはじめ 8 種類のナッツ類に対し, AF 污染に対 する規制が設けられ，この試験法の適用が指示された22.

この試験法には，1回の分析に必要な量が $50 \mathrm{~g}$ とさ れているが, 試料のサンプリング方法については示され

*1 食品中の Mycotoxin に関する研究（第 5 報）

*2 名古屋市衛生研究所：名古屋市瑞穂区萩山町 1-11
ていない，殊に，落花生については行政需要から，昭和 46年 3 月以後54年まで検査を実施してきたが，暫定的に

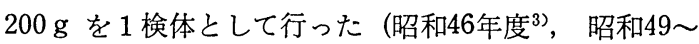
54年度 ${ }^{4)}$. しかし，この検体量では，AF が検出された ものと同一の口ットでも，再検查すると定量值が大きく 異なったり，一方は検出しないという結果を生じること がある. 特に, 別々の検查機関からプラス, マイナスの 相反する結果が提出されるに及んでは, 行政措置の根拠 となるべき検查機関の成績としては説得力に久けるもの である.

落花生の AF 検査におけるサンプリングに関する研 
究の主なるものにWhitaker ${ }^{5 \sim 7)}$ 及び Knütti ${ }^{8)}$ らの報告 がある.これらは，母集団について污染度の母平均を推 定する方法について検討されており，特に AF 污染粒 の不均一な分布によって, 污染品を非污染品と判定した り（消費者りスク），また非污染品を污染品と判定する （生産者リスク）過䛊を，負の二項分布法則により，殊に サンプル量との関係から推計し， 10,000 粒 (3〜 $5 \mathrm{~kg})$ 以上のサンプリングの必要なことを述べている．しか し，著者らの実施する市場調查では，一つの店頭から， 同一の商品をそのように多量収集できないし，一たん流 通段階に流れてしまって消費されつつあるものの母集団 推定は，口ット全体からまんべんなくサンプリングでき ないので不可能である，従って，著者らの役割は，陸揚 げ後の再污染がもしあれば, それも含めて消費者りス ク，すなわち，基準より高い污染集団を摘発し，消費者 を $\mathrm{AF}$ の危険から防ぐことにあると考えられる.

特に, 問題となるのは, 極めて少数の AF 污染粒の混 在であっても， 1 粒の污染度が高いためサンプル全体と しては AF が検出する場合である.すなわち，この污染 粒局在形のロットでは，最初の何回かのサンプリングに よる検査では検出しないといら結果を得ても, 検査回数 を増せば,いつかは AF 污染粒を捉えることになる. 同 時に, 検査結果の不一致による混乱をひき起こすことに なる。

環食第 128 号の通達による方法では, 行政上検出限度 を $10 \mathrm{ppb}$ と定め, それ以下は検出しないと判定するよ ら指示されている. 同様に, 污染粒率についても一定の 検出限度を定め，これらの両面から AF 污染を捉える ことにより，いたずらに検査回数を增すことへの雨止め と, 検査結果の不一致に対し生ずる混乱を少くすること ができるものと考えられる。

著者らは，このような観点に立って，最少量のサンプ ルで, AF 污染品の検索と污染粒率の推定のできるサン プリング方法を，二項分布法則に基ついて考案し，実態 調查への応用を試みたので報告する.

2. 理

市販品の調査という点に鑑み, 同一の商品の 1 ロット を母集団と考え，そこより任意に抜き取った複数の包装 単位の各々をサブサンプル，サブサンプルを統合したも のをサンプルと呼ぶことにする.ここで，入手したサン プル中に, AF 污染粒が 1 粒でも混入していれば，必ず AF が検出できるものとする.

環食第 128 号の方法では, 実験上の検出限度は $1 \mathrm{ppb}$ であるから，仮りに $500 \mathrm{~g}$ をサンプルとしたとき，もし 1 粒のみに AF 污染が存在したとすると， 1 粒中に AF $\mathrm{B}_{1}$ は $0.5 \mu \mathrm{g}$ 以上存在する必要がある.

\section{2-1 污染度の推定に必要なサンプル量}

污染粒率 $p$ の母集団から, サブサンプルとして $n$ 粒 を取り出したとき，その中に污染粒が $k$ 粒入っている確
Table 1. Probability of Occurence of Aflatoxin Contaminated Kernels in a Subsample Taken from a Lot with Contaminated Proportion of $0.1 \%$ or $0.5 \%$ in Kernel Number

\begin{tabular}{|c|c|c|}
\hline \multirow{3}{*}{$\begin{array}{c}\text { No. of } \\
\text { contaminated } \\
\text { kernels in } \\
\text { subsample } \\
k / 200 \mathrm{~g} \\
(n=500)\end{array}$} & \multicolumn{2}{|c|}{$\begin{array}{c}\text { Probability of } k \text {-occurence } \\
\operatorname{Pr} \% *\end{array}$} \\
\hline & \multicolumn{2}{|c|}{$\begin{array}{l}\text { Percentage of contaminated } \\
\text { proportion in kernel } \\
\text { number, } p\end{array}$} \\
\hline & $0.1 \%$ & $0.5 \%$ \\
\hline 0 & 60.6 & 8.2 \\
\hline 1 & 30.3 & 20.5 \\
\hline 2 & 7.6 & 25.7 \\
\hline 3 & 1.3 & 21.4 \\
\hline 4 & 0.2 & 13.4 \\
\hline 5 & 0.0 & 6.7 \\
\hline 6 & 0.0 & 2.8 \\
\hline 7 & 0.0 & 1.0 \\
\hline
\end{tabular}

* Probability of $k$-occurence was calculated based on the formula,

$\operatorname{Pr} \%=\frac{n !}{k !(n-k) !} p^{k}(1-p)^{n-k} \times 100$

率 $\operatorname{Pr} \%$ は, 二項分布法則に従らものと考兄られ, 確率 式 $\operatorname{Pr} \%$ は (1) 式で与えられる

$$
\operatorname{Pr} \%=\frac{n !}{k !(n-k) !} p^{k}(1-p)^{n-k} \times 100
$$

ここで, 著者 ${ }^{10)} 及 ひ ゙ ~ C u c u l l u u^{11)}$ らの報告では, 通常 $0.1 \sim 0.5 \%$ の污染粒率のものに遭遇する機会が多いこ と, また，それ以下の污染粒率のものを追求しても偶然 性に左右され, 再現性に乏しく, 再び污染粒を捉えよう としても困難であることから，0.1\% 以上のものを検索 の対象とした.

Table 1 には，0.1\% 及び $0.5 \%$ 污染粒率について, 500 粒を抜き取った場合, そのうち $k$ 粒が污染している 確率を示した（通常污染のよく見つけられるスパニッシ 二種の落花生では, 約 $200 \mathrm{~g}$ に相当する).

ここで, 污染粒率 $0.1 \%(p=0.001)$ に拈いて, サブ サンプルとして 500 粒 $(n=500)$ を取り出したとき, 污 染粒を 1 粒 $(k=1)$ 取り出す確率は, $\operatorname{Pr}=30.3 \%$ と計 算され，さらに $k=2 ， 3 ， 4$ の場合， Pr はそれぞれ 7.6, $1.3,0.2 \%$ となり，1 粒以上 4 粒まで含まれる確率は， これらの合計 $39.4 \%$ である.ここで初めの数回に及ぶ 500 粒づつの抜き取りによっても，残った母集団中の污 染粒率に何ら影響を及ぼさないほど母集団の量が十分多 いと考えると（通常, 菓子製造には, 何百 $\mathrm{kg}$ の単位で 同一のロットが製造されるので，母集団としては十分量 と考えてよい), 合計 3 つのサブサンプル,すなわち 3 回 分 $(500$ 粒 $\times 3)$ を抜き取ると, そのうち 1 回は污染粒を 
1 粒以上取り出せる可能性が高い(確率 $77.7 \%$ ), 一方, $k=0$ ，すなわち， 1 つのサブサンプル中に 1 粒も污染粒 を取り出さない確率は $60.6 \%$ と高く， 3 回に 2 回は $k=0$ と考光られる. この $k=0$ の事象が連続して 3 回起 きる確率は， $22.3 \%\left(0.606^{3} \times 100\right)$ であり，言い替えれ ば，この 1 回 500 粒のサブサンプルを 3 回くり返し，そ れを 1 組としたサンプル構成では， 5 組のサンプル中， 1 組には污染粒が 1 粒も含まれないことになる（不検出 率 $20 \%$ ).

また，污染粒率 $0.5 \%$ の場合，1つのサブサンプルと して 500 粒取り出して, その中に 1 粒も污染粒を取り出 さない確率は $8.2 \%$ と小さく, 逆に 1 粒以上污染粒の含 まれている確率は $91.8 \%$ であるから，10回抜き取って も 9 回は検出する.このような考元方から，500 粒 (200 g) 内容のものであれば，最低 3 回以上サブサンプルと して抜き取る必要がある.

\section{2-2 污染粒率の推定}

二項分布式（1）において，1粒も污染粒を取り出さな い場合， $k=0$ と置けば，そのときの確率は（2）式で表 わされる。

$$
\operatorname{Pr} \%=(1-p)^{n} \times 100
$$

ここで，サブサンプルの粒数 $n$ は実測できるから， (2) 式のPr\% が明らかとなれば，污染粒率 $p$ は算出で きる. たとえば，五つのサブサンプルのらち三つが検出 し，二つが不検出であれば， $k=0$ の確率を $40 \%(2 / 5)$ と考えて $p$ を推定することができる.さららすべての サブサンプルから AF が検出された場合は, 污染粒率は $(1 / n) \times 100 \%$ 以上であるが，ここで再度サンプリング をすることができれば，サブサンプルを適当な数に等分 し，ミニサブサンプルを調製し同様に検查し，すべての ミニサブサンプルのうち 1 つでも不検出があれば， $k=0$ の確率が定まるから污染粒率 $p$ は推定できる.

\section{3. 実験方法}

\section{3-1 分析試料の調製}

\section{3-1-1 1 包装単位が $500 \mathrm{~g} \sim 1 \mathrm{~kg}$ の場合}

サンプルを粉砕せずに, 粒状のまま必要数に応じて等
分し (Scheme 1, 5 等分の例を示した)， サブサンプル 1〜5を調製し，それぞれ別々にカップ・ナイフ付のジ ニーサーミキサー $(700 \mathrm{ml})$ で粉砕し，1つのサブサン プル分を同一のポリエチレン製袋に入れよく混合し，そ れぞれのサブサンプルより同量づつ分取し，別の袋に入 れ混合し, 統合サブサンプル 120１50 g を調製した(サ ンプルの代表とする).

\section{3-1-2 包装内容が $500 \mathrm{~g}$ 以下の場合}

総量で $500 \mathrm{~g}$ 以上となるように，数個のサブサンプル を収集し，3-1-1 の場合と同様に，別々に粉砝し，同量 づつ分取し，統合サブサンプル（サンプルの代表）を調 製した.

\section{3-2 アフラトキシンの定量}

統合サブサンプルより $50 \mathrm{~g}$ を分取し，環食第 128 号 の方法により AF の試験をした.試料をメタノール：1\% 食塩水 $(55: 45, \mathrm{v} / \mathrm{v})$ 及び $n$-ヘキサンと共に抽出し， メタノール水層をクロロホルムで抽出後, クロロホルム 抽出物を濃縮し, シリカゲルカラム (Kieselgel 60, Art 7734, Merck 社製, $10 \mathrm{~g}$ ) に吸着させ, $n$-ヘキサン, エ チルメーテルの順に洗い，クロロホルム：メタノール $(97: 3, v / \mathrm{v})$ にて溶出し, 溶媒を留去後, ベンゼン: ア セトニトリル $(98: 2, \mathrm{v} / \mathrm{v})$ に溶かし薄層クロマトグラフ ィー (TLC) 用試料とした.

TLC 分析には, 既製のプレート (Kieselgel 60, Art $5721,20 \times 20 \mathrm{~cm} \mathrm{Merck}$ 社製) を用い, 試料と同時に AF $B_{1}, B_{2}, G_{1}, G_{2}$ 標準 (Makor 社製)をスポットし, クロロホルム:アセトン $(9: 1, \mathrm{v} / \mathrm{v})$ で展開後, $365 \mathrm{~nm}$ の紫外線照射下に発する篮光を, デンシトメトリーによ って (島津 High Speed TLC Scanner CS-920) 比色定 量した.

第 1 回目の分析で, AF が検出されなければ，該当す るサブサンプルはすべて AF は検出しないものとし(従 ってサンプルも不検出と判定する), 1 回目の分析で $\mathrm{AF}$ が検出されたら，もら一度統合サブサンプルより $50 \mathrm{~g}$ を取り，2 回目の分析を行い， 2 回の平均值を以って統 合サブサンプル及びサンプルの $\mathrm{AF}$ 污染度とした. $\mathrm{AF}$

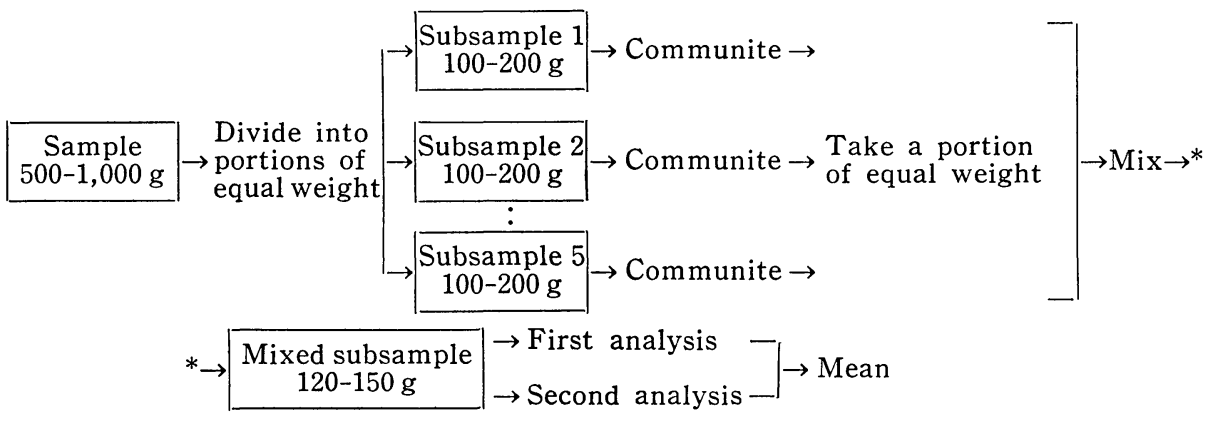

Scheme 1. Sampling and analytical plan for aflatoxin analysis of grainy peanut and nut products 
が検出された場合は，すべてのサブサンプルの AF を定 量し，サブサンプル間の変動を調べると同時に，污染粒 率の推定を行った.

\section{4. 実験結果及び考察}

昭和56年及び57年に名古屋市内より収集した落花生及 びナッツ製品など 144 検体の調査で, AF が検出された もののらち, 詳しく追跡調査できた 3 例につきサブサン プル及び統合サブサンプルの AF 定量值並びに, 污染粒 率の推定値を Table 2 に示した.

ロットNo. 1 は, シリア産のスパニッシュ種で, 保健 所よりサブサンプル No. 1 及び 2 の 2 袋が当初搬入さ れた，外観は，粒のまま穀粉に食塩など調味し，コーテ ングして焼いた加工品であった。この検体は，当初本調 查計画に基づくサンプル量に満たなかったが，とりあえ ず2 袋につき分析したところ $\mathrm{AF} \mathrm{B}_{1} 1580 \mathrm{ppb}$ 検出され た. 直ちに行政当局に連絡し，追加のサブサンプル 4 袋 (Table 2, No. 3〜6) を入手し検査した. 6 袋の AF $\mathrm{B}_{1}$ は，不検出から $2040 \mathrm{ppb}$ と広い範囲にばらつき，全平
均值は $418 \mathrm{ppb}$ であった. 行政当局により全該当口ット の回収命令が出された（昭和56年 9 月）.

污染粒率の推定は, 1 粒の平均重量が $0.527 \mathrm{~g}$ であっ たので，1袋には約 300 粒が入っていたと計算される. そこで $n=300$ 之置き, 6 回の検查のうち 1 回だけ不検出 であったから，16.7\% (1/6) が AF 污染粒を 1 粒も含ま なかった確率と考えれば，(2) 式は，16.7= $(1-p)^{300} \times$ 100 となるから, $p=0.0060$ すなわちこのロットの污染 粒率は $0.60 \%$ と推定された。

ロットNo. 2 も No. 1 と同様の形態をした加工品で あったが，原料豆はスーダン産のスパニッシュ種であっ た.この検体は， $500 \mathrm{~g}$ 入り 1 袋（サブサンプル No. 1) が保健所より搬入された，AF $\mathrm{B}_{1} 41.9 \mathrm{ppb}$ が検出され た.しかし，この製品については，以前関係業態から同 一のロットと思われる製品の依頼検査を当所において行 い，その時は検出しなかったので，さらに詳しく調査す るため $2 \mathrm{~kg}$ を追加入手し，これを 4 分して約 $500 \mathrm{~g}$ の サブサンプルとし，AF の検查を行った. 全サブサンプ

Table 2. Analytical Results of Aflatoxins in Subsamples and Combined Subsamples and Estimated Percentages of Contaminated Proportions in Kernel Number

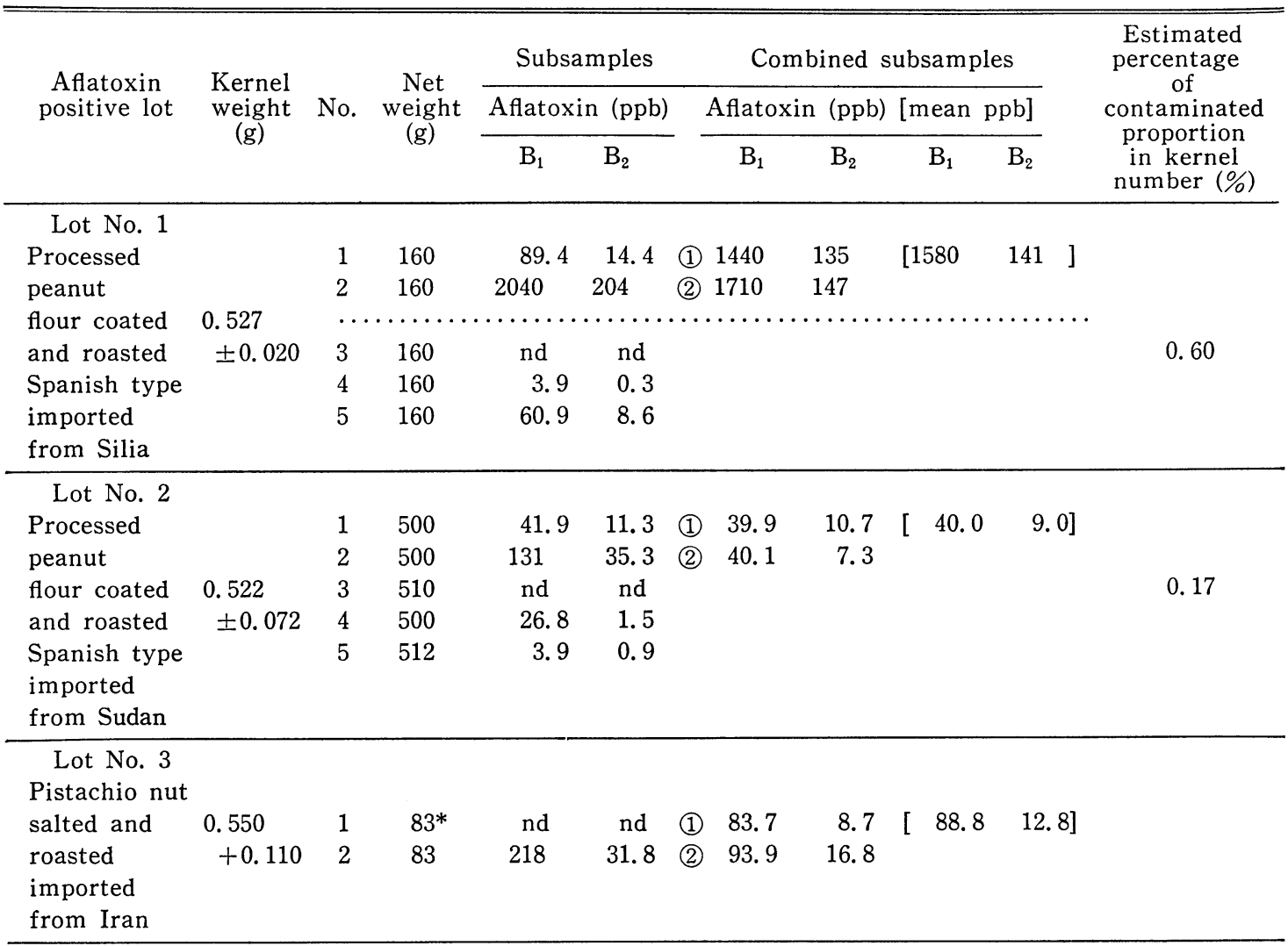

* shelled and $55 \%$ of original weight

(1) first analysis (2) second analysis 
ルの平均 $\mathrm{AF} \mathrm{B}_{1}$ 污染度は $40.0 \mathrm{ppb}$ であり（範囲, 不検 出から $131 \mathrm{ppb})$, 該当加工品の廃棄処分之, 保蔵原料豆 約 6 トンにつき，行政指導によって不良品の選別除去が 行われた (昭和56年11月).

このロットの污染粒率は, $500 \mathrm{~g}$ が約 960 粒と換算さ れたから， $k=0$ の時の $\operatorname{Pr}=20 \%$ より，(2) 式は，20= $(1-p)^{960} \times 100$ となり，污染粒率 $p$ は $0.17 \%$ と推定さ れた.

ロット No. 3 は, イラン産のピスタチオナッツであ り，東京都の発表により検查したものであるが，発表と 同時に大部分は市場から回収されていて，2 袋の及搬入 されたので污染粒率の推定は無理である.

これらの結果は, $0.1 \%$ 污染粒率のものを検索の対象 とした当初の計画と一致し，本計画の実用性を示してい るものと思われる.

理論の項でも少し触れたように，0.1\% 以下の污染粒 率のものを追跡するには，本実験で行われたサンプル量 の数倍以上を必要とするため, $0.1 \%$ 程度が実際には限 度と考兄られる. 従って污染粒率の推定で $0.1 \%$ 以上の 計算值が得られ, AF $\mathrm{B}_{1}$ の污染度が $10 \mathrm{ppb}$ を超えた場 合にはじめて行政当局に連絡するなどの基準の設定も考 えられる.すなわち，500 粒づつの検查で，5回検査し た場合, 4 回は不検出で 1 回検出したとすると, 污染粒 率は, $0.045 \%$ と計算される. 一方 2 回検出し, 3 回検 出しないという場合は, $0.1 \%$ と計算される. 従って, 5 回の検查で 2 回以上検出すれば, 污染粒率の推定值は $0.1 \%$ 以上となる. このように全統合サブサンプルの污 染度 (サンプルの污染度) と污染粒率の両方から一定の 基準設定が， $\mathrm{AF}$ 污染の判定の手段として有効と考えら れる. 本報では, 技術上 (サンプルの入手の面から) 0.1 \%を一つの目安としたが， AF の毒性の評価の中で，今 後 $\mathrm{AF}$ 污染粒の局在性と発ガンの危険性との間に, 一定 の相関性が見出されるなら，0.1\% の仮の提案基準は， 変更されるべきものと考えられる.
污染粒率の推定に必要なサブサンプル数について少し 考察すると, サブサンプル数が多ければ, それだけ正確 な推定ができる．しかし，本実験計画の原則である少量 のサンプルといら点で, 総量で $1 \mathrm{~kg}$ までと考学られ, 5 10 個のサブサンプルで推定せざるを得ない. ロット No. 2 のサンプルでは, 追加サブサンプルを製造元から 入手できたので, 総計 $2.5 \mathrm{~kg}$ のサンプルで判定したが, あまりよい応用例とは言兑ない。しかし，行政処分の対 象になる場合には, 特別に可能な限りサンプル量を多く する必要はある.

污染粒率の誤差に関しては, もら一つ問題がある. (2) 式より，k=0 の確率は，Pr\% の小さいときに, 少 しの数の变化にも，污染粒率 $p$ は大さ变動し，Pr\% が大きくなるときわめて変動が小さくなる．たとえば, $n=500$ のとき, $k=0$ の確率が $P r=20 \%$ のとき, $p$ は $0.32 \%, P r=50 \%$ のとき $p$ は $0.14 \%, P r=80 \%$ のと き, $p$ は $0.04 \%$ となることから理解され, 污染粒率 $p$ の推定誤差を少くするには, サブサンプル数を多くする ことと, $k=0$ の確率で, $\operatorname{Pr}$ の高いところで $p$ を求める 努力が必要である.

なお参考のため, 144 検体の $\mathrm{AF}$ 検出状況を Table 3 に示した. 生の落花生は, 主に流通段階にある原料チェ ックのため, 加工品に $\mathrm{AF}$ が検出された場合, 関係業態 の保蔵品を検査したものである. 生の落花生28検体中, $10 \mathrm{ppb}$ を超光た 6 検体と, $10 \mathrm{ppb}$ 以下の 3 検体は, $\mathrm{AF}$ の検出された加工品の原料として保蔵されていたもので あり，スーダン及びブラジル産のスパニッシュ種であっ た。ナッツ類では, 東京都衛生研究所の調査により, AF 污染が明らかにされたものと同系統の輸入品と思われる イラン産のピスタチオナッツ1検体に $\mathrm{AF}$ が検出され た.

サンプリング誤差に関する研究報告は, Whitaker ${ }^{12)}$ 及び Knütti ${ }^{8)}$ らの他に, Stoloff ${ }^{13,14)}$, Timstra ${ }^{15)}$, Schade ${ }^{16)}$ らの報告もあるが, Whitaker は負の二項分

Table 3. Analytical Results of Aflatoxin $B_{1}$ in Retailed Peanut and Nut Products (19811982)

\begin{tabular}{|c|c|c|c|}
\hline \multirow[t]{2}{*}{ Sample } & \multirow[t]{2}{*}{ No. of sample } & \multicolumn{2}{|c|}{$\begin{array}{l}\text { No. of Aflatoxin positive sample } \\
\text { (Range of contamination } \\
\text { mean value of positive }\end{array}$} \\
\hline & & $\mathrm{AF} \mathrm{B}_{1}>10 \mathrm{ppb}$ & $\mathrm{AF} \quad \mathrm{B}_{1} \leqq 10 \mathrm{ppb}$ \\
\hline $\begin{array}{l}\text { Peanut } \\
\text { Raw }\end{array}$ & 28 & $9 \quad\left(\begin{array}{c}14.8-482 \\
138\end{array}\right)$ & $3\left(\begin{array}{c}\operatorname{tr}-5.6 \\
3.3\end{array}\right)$ \\
\hline Processed & 75 & $7 \quad\left(\begin{array}{c}10.1-1,580 \\
307\end{array}\right)$ & $2\left(\begin{array}{c}2.0-8.5 \\
5.3\end{array}\right)$ \\
\hline \multicolumn{4}{|l|}{ Nut } \\
\hline Pistachio nut & 15 & $(88.8)$ & 0 \\
\hline Others & 26 & 0 & 0 \\
\hline Total & 144 & 17 & 5 \\
\hline
\end{tabular}


Table 4. Distribution of Subsample Weight

\begin{tabular}{lccccc}
\hline \hline & \multicolumn{5}{c}{ No. of subsample in weight range } \\
\cline { 2 - 6 } Sample & $x \leqq 100$ & $100<x \leqq 200$ & $200<x \leqq 500$ & $500<x \leqq 1000$ & $1000<x \leqq 2000 \mathrm{~g}$ \\
\hline $\begin{array}{l}\text { Peanut } \\
\text { Raw }\end{array}$ & 2 & 35 & 29 & 20 & 8 \\
$\quad$ Processed & 9 & 18 & 14 & 9 & 8 \\
Nut & & & & 29 \\
$\quad$ Product & 11 & 53 & 43 & & \\
\hline Total & & & & & \\
\hline
\end{tabular}

$x$ : Net weight of subsample

布法則に基づいて, operating characteristic curve (OC 曲線) を作製し，消費者リスク及び生産者リスクを 指標として, サンプリングプランの数量関係を評価し た. そして，サンプルを大きくすることが，母集団の真 の平均値に近づくことを述べている $(12,000 ３ 5,000$

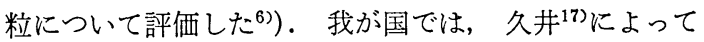
Whitaker の考方方が，1972～1976年の輸入落花生の検 査データを基にして具体的に紹介された。 それによれ ば, $\mathrm{AF} \mathrm{B} \mathrm{B}_{1}$ の真の母集団平均濃度が $5 \mathrm{ppb}$ の場合, そ の中には，なお $10 \mathrm{ppb}$ を超す部分（ロット）が存在し， たとえ 10,000 粒抜き取って検査しても，その部分を 10 $\mathrm{ppb}$ 以下と判定する消費者リスクは $5.4 \%$ であるとい う. 従って, AF 分布の不均一性が高い程, リスクは避 け難い。

我が国では，輸入落花生に対して昭和 46 年 3 月，厚生 省環食第 132 号の通達で，また輸入のナッツ類 8 種に対 しては，56年 9 月環食第 202 号の通達で各港の検疫所・ 駐在官あてにサンプリング方法が示された ${ }^{18)}$. 落花生で は 1 ロットにつき $1 \mathrm{~kg}$ (大粒種で約 1,000 粒, 小粒種で 約 3,000 粒) がサンプル量として指定された.この量は, Whitaker らが必要と認めている 10,000 粒以上より少 く，現在米国の食品工業界で実施されている48ポンドつ つ, 污染段階別に 3 回サンプリングする方法 ${ }^{19)}$, 西ドイ ツで行われている $5 \mathrm{~kg}$ 法 ${ }^{19}$ に比べると母平均を推定す るには少な過ぎる.むしろ，定性的に AF 污染をチェッ クする方法と理解される. 従って, 消費者リスクも 10,000粒以上サンプリングに比べて高く現われていると 考えられるから, 流通段階で再チェックする必要があ る.一方，ナッツ類では，口ットの大きさにより，1〜 $4.5 \mathrm{~kg}$ の抜き取りを指示しているが，米国で実施され ている，ブラジルナッツ及びピスタチオナッツの30〜60 ポンドサンプリングに比べれば少い，本調查で污染が明 らかとなったロットNo. 1，2 は，この消費者リスクの 部分を捉えたものであろう.な和污染口ットNo. 3 ( Ta. ble 2) のピスタチオナッツは，56年 9 月の規制設定以前 の輸入品であった.

なお，理論の項で，200 g（500 粒）を代表例として説
明したのは, 市販品では $200 \mathrm{~g}$ 前後の包装内容のものが 最も多かったからであり, Table 4 に今回調查した検体 の, サブサンプルの内容量の分布を示した.

最後に，この調査に用いたサンプリング方法は, 落花 生, ナッツに限定しなくとも, 粒状が一定の重量, 体 積, 形態を持ったものなら適用できるものと考えられ る. そして, 本研究のサンプリング方法の根拠として, 二項分布法則に従ったが，ポアソン分布法則によって も, 全く同様の数的評価のできることを確めた ${ }^{20)}$.

本調查研究費の一部は, 昭和 56 年度厚生省ガン研究助 成金により行った.

終りに臨み, 本研究に当り, 御指導賜った国立予防衛 生研究所・粟飯原景昭博士並びに国立衛生試験所・一戸 正勝博士に深甚の謝意を表明します。なお，本研究の要 旨は日本第17回マイコトキシン研究会 (1983年 2 月, 東 京）において発表した。

\section{文献}

1) 厚生省食品衛生課, 乳肉衛生課, 食品化学課編： 食品衛生研究 21, 564 567 (1971).

2) 同上: 31, 915 (1981).

3) 山本勝彦, 田村征男, 森山繁隆, 坂部美雄, 青木 良雄：名市衛研報．19，127～132 (1972).

4) 山本勝彦, 坪内春夫, 久田和夫, 坂部美雄: 同 上. 26, 48 51 (1979).

5) Whitaker, T. B., Wiser, E. H.: J. Amer. Oil Chem. Soc. 46, 377 379 (1969).

6) Whitaker, T. B., Dickens, J. W., Wiser, E. H.: ibid. 47, 501 504 (1970).

7) Whitaker, T. B., Dickens, J. W., Monroe, R. J., Wiser, E. H.: ibid. 49, 590 593 (1972).

8) Knütti, R., Schlatter, C.: Z. Lebensm. Unters. Forsch. 174, 122 128 (1982).

9）依田 浩：“技術者の統計学” p. 81～84 (1961) 宝文館。

10) 山本勝彦, 田村征男, 坂部美雄, 森山繁隆: 名市 衛研報。19, 47 52 (1972).

11) Cucullu, A. F., Lee, L. S., Mayne, R. Y., Gold. 
blatt, L. A.: J. Amer. Oil Chem. Soc. 43, 89 92 (1966).

12) Whitaker, T. B., Dickens, J. W.: ibid. 51, 214 218 (1974).

13) Stoloff, L., Campbell, A. D., Beckwith, A. C., Nessheim, S., Winbush, J. S. Jr, Fordham, D. M. Jr: ibid. 46, 678 684 (1969).

14) Stoloff, L., Dantzmann, J., Wegner, J.: ibid. 49, 264 266 (1972).

15) Tiemstra, P. J.: ibid. 46, 667 672 (1969).
16) Schade, J. E., King, A. D., Mackey, B. E., Halbrook, W. V., Fuller, G.: ibid. 58, 852 857 (1981).

17） 久井伸治：“公害と対策” 15, 417〜423 (1979).

18）厚生省食品衛生課, 乳肉衛生課, 食品化学課編： 食品衛生研究 31, 913 (1981).

19) Campbell, A. D.: Pure Apll. Chem. 52, 205 211 (1979).

20）春田三佐夫：食品検查ニュース 83-No. 1 (1983) 栄研化学 (株) 発行. 